\title{
Formation of Anionic Peptide Radicals In Vacuo
}

\author{
Corey N. W. Lam and Ivan K. Chu \\ Department of Chemistry, University of Hong Kong, Hong Kong, China
}

\begin{abstract}
In this paper, we demonstrate for the first time the formation of radical anionic peptides [M $2 \mathrm{H}^{--}$through a one-electron transfer mechanism upon low-energy collision-induced dissociation (CID) of gas-phase singly charged $\left[\mathrm{Mn}^{\mathrm{III}}(\text { salen })(\mathrm{M}-2 \mathrm{H})\right]^{--}$complex ions [where salen is $\mathrm{N}, \mathrm{N}^{\prime}$-ethylenebis(salicylideneiminato) and $\mathrm{M}$ is an angiotensin III derivative]. The types of fragment ions formed from $[\mathrm{M}-2 \mathrm{H}]^{-}$share some similarities with those from the cationic radical peptides $\mathrm{M}^{+}$and $[\mathrm{M}+\mathrm{H}]^{2+}$, but differ significantly from those of the corresponding deprotonated peptides $[\mathrm{M}-\mathrm{H}]^{-}$. Fragmentation of $[\mathrm{M}-2 \mathrm{H}]^{--}$radical anionic angiotensin III derivatives leads preferentially to product ions of side-chain cleavage of amino acid residues, z-type and minor x-type fragment ions, most of which are types rarely observed in low-energy CID spectra of deprotonated analogs. The degree of competitive dissociation of the complexes is highly dependent on the nature of the substituted salen derivatives. The yields of anionic peptide radicals were enhanced to the greatest extent when electron withdrawing groups were positioned at the 5 and $5^{\prime}$ positions, but the effect was rather modest when such groups resided at the 3 and $3^{\prime}$ positions. Substituting a cyclohexyl unit of a salen with phenyl or naphthyl moieties at the 8 and $8^{\prime}$ positions also facilitated electron-transfer pathways. (J Am Soc Mass Spectrom 2006, 17, 1249-1257) (c) 2006 American Society for Mass Spectrometry
\end{abstract}

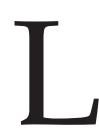
ibrary searches of the electron impact ionization (EI) mass spectra of small organic radical cations recorded at $70 \mathrm{eV}$ are often performed to identify and quantify unknown compounds because of the reproducibility and structure-specific nature of the dissociation products in EI spectra. EI has been used, only sparingly, however, for the characterization of peptides because of their low volatility; indeed, only a few EI spectra of peptides have been reported [1,2]. The use of laser desorption and multiphoton ionization circumvents the issue of the nonvolatility of peptides [3-5], but it is applicable only to peptides that contain aromatic chromophore units. In this process, neutral peptides are transferred into the gas phase through laser desorption and then ionized through two-photon UV ionization of their aromatic chromophore units. More recently, Beauchamp et al. demonstrated another novel method for generating radical cationic peptides: dissociating $\mathrm{N}$-derivatized peptides possessing a conjugated free radical initiator positioned at their $\mathrm{N}$-terminus [6]. The capture of low-energy electrons, which results in electron capture dissociation (ECD), is an alternative method [7-11] for converting a multiply protonated peptide into a protonated peptide radical cation, [M + $\mathrm{nH}]^{(\mathrm{n}-1)+}$. In contrast to protonated peptides that fragment predominantly through cleavage of a peptide

Published online June 30, 2006

Address reprint requests to Dr. I. K. Chu, Department of Chemistry, University of Hong Kong, Pokfulam Road, Hong Kong, China. E-mail: ivankchu@hku.hk bond to form $\mathrm{y}$ and $\mathrm{b}$ ions, the dissociation of protonated peptide radical cations requires cleavages of $\mathrm{N}-\mathrm{C}_{\alpha}$ bonds to form predominantly $\mathrm{c}$ and $\mathrm{z}$ product ions [7-12]. Fragmentation of peptide radical cations also provides an analytical means for de novo sequencing, especially for locating post-translational modifications, improves the sequence coverage relative to that attainable from protonated species, and allows the differentiation of isomeric leucine and isoleucine residues in oligopeptides [7-11].

Despite some recent advances in the preparation of peptide radical cations, their reactivity and fragmentation mechanisms remain poorly understood. The nonergodic dissociation mechanism (i.e., without intramolecular vibrational redistribution before unimolecular fragmentation) postulated for relatively large biomolecules remains under investigation and debate [10, $12-15]$, even though the findings are of fundamental importance to biological tandem mass spectrometry [16]. Comprehensive studies of radical peptide systems have been hindered by difficulties in generating them and the need for special instrumentation. Although initially this approach was feasible only when employing Fourier transform ion cyclotron resonance (FT-ICR) mass spectrometers, a similar technique, which relies on electron transfer, was demonstrated recently using commercial ion trap instruments $[17,18]$ and has attracted considerable interest. To the best of our knowledge, only a few reports have been published so far describing studies of the fragmentation of odd-electron peptide radical anions, which have been generated 
mainly through high-energy collisional excitation with a target gas and electron transfer within an accelerator mass spectrometer [19] and electron capture dissociation in an FT-ICR mass spectrometer [20].

Recent reports on the generation of cationic radical peptides (i.e., $\mathrm{M}^{+}$and $[\mathrm{M}+\mathrm{H}]^{.2+}$ species) have focused on the CID of copper(II) (or trivalent) metal complexes containing an auxiliary ligand and a peptide. Our attempts at the gas-phase dissociation of copper(II) complex peptide complexes when using quadrupole ion trap instruments have led to the generation of [M + $\mathrm{H}^{2+}$ radical cationic peptides through one-electron transfer [21]. Fragmentation of doubly charged [M + $\mathrm{H}]^{2+}$ radical cations generates similar product ions to those prepared through hot electron capture dissociation (HECD) $[8,22]$. The dissociation of $[\mathrm{M}+\mathrm{H}]^{2+}$ species is similar to that of the corresponding peptide radical cations $\left(\mathrm{M}^{+}\right)$, but it is significantly different from those of the corresponding even-electron protonated peptide ions $[\mathrm{M}+\mathrm{H}]^{+}$and $[\mathrm{M}+2 \mathrm{H}]^{2+}$. The latter systems fragment predominantly through amide bond cleavage to form $\mathrm{y}$ and $\mathrm{b}$ ions, whereas the peptide radical cations fragment through cleavage of $\mathrm{N}-\mathrm{C}_{\alpha}$ bonds to form $\mathrm{c}$ and $\mathrm{z}$ product ions and side-chain cleavage to generate $\mathrm{w}^{+}$product ions. Isomeric isoleucine and leucine residues can be distinguished by observing the mass differences between the $\left[\mathrm{z}_{\mathrm{n}}+\mathrm{H}\right]^{+}$ and $\mathrm{W}_{\mathrm{n}}{ }^{+}$ions (having the same residue number, $\mathrm{n}$ ) of the $\mathrm{Xle}$ residues.

The significance of this CID methodology extends to the possibility of synthesizing hydrogen-deficient radical anionic peptides, $[\mathrm{M}-2 \mathrm{H}]^{--}$. The ability to produce odd-electron radical cationic $\mathrm{M}^{++}$and $[\mathrm{M}+\mathrm{H}]^{+}$and anionic $[\mathrm{M}-2 \mathrm{H}]^{--}$peptides would allow us to explore how the nature of the charge-carrying group of these radical peptides-molecular cations and hydrogendeficient cations and anions-affects the nature of their competitive dissociation pathways. This challenge has provided the impetus to obtain a better understanding of how the roles played by the hydrogen atom and radical sites govern the mechanisms of radical peptide fragmentation. In this study, we extended our investigations toward the synthesis of novel anionic radical peptides by using a similar methodology incorporating one-electron transfer. We have conducted the first study into the generation and identification of a series of angiotensin III derivatives of the hydrogen-deficient radical anions of the type $[\mathrm{M}-2 \mathrm{H}]^{--}$that differ only by one residue.

\section{Experimental}

\section{Mass Spectrometry}

All mass spectrometry experiments were conducted using a quadrupole ion trap mass spectrometer (Finnigan LCQ, ThermoFinnigan, San Jose, CA). Samples typically comprised $600 \mu \mathrm{M} \mathrm{Mn}$ (III) complex and 50 $\mu \mathrm{M}$ peptide in a water/methanol (50:50) solution. Sat- urated ammonium acetate $(0.5 \mu \mathrm{L})$ was added to the samples $(500 \mu \mathrm{L})$. These samples were infused continuously at a typical rate of $5 \mu \mathrm{L} / \mathrm{min}$ into the pneumatically assisted electrospray probe using air as the nebulizer gas. CID spectra of $\left[\mathrm{Mn}^{\mathrm{III}}(\mathrm{L})(\mathrm{M}-2 \mathrm{H})\right]^{--}$ complexes were acquired using helium as the collision gas. The injection and activation times for CID in the ion trap were 200 and $30 \mathrm{~ms}$, respectively, and the amplitude of the excitation was optimized for each experiment.

\section{Materials}

All chemicals were obtained commercially (Aldrich and Sigma, St. Louis, MO). Angiotensin III derivatives were synthesized according to literature procedures [23]. $\mathrm{N}, \mathrm{N}^{\prime}$-Ethylenebis(salicylideneiminato) (salen) and its substituted derivatives possessing different steric and electronic properties, including N,N'-bis(5-tert-butylsalicylidene)-o-ethylenediamine $\left[5,5^{\prime}-\left({ }^{\mathrm{t}} \mathrm{Bu}\right)_{2}\right.$-salen $], \quad \mathrm{N}, \mathrm{N}^{\prime}-$ bis(5-nitrosalicylidene)-o-ethylenediamine $\left[5,5^{\prime}-\left(\mathrm{NO}_{2}\right)_{2}{ }^{-}\right.$ salen], $\mathrm{N}, \mathrm{N}^{\prime}$-bis(salicylidene)-o-cyclohexyldiamine (salchda), N,N'-bis(salicylidene)naphthylene-2,3-diamine (dsn), N, N'-bis(salicylidene)-o-phenyldiamine (salophen), N,N'-bis(3-tert-butylsalicylidene)-o-ethylenediamine $\left[3,3^{\prime}-\left({ }^{\mathrm{t}} \mathrm{Bu}\right)_{2}\right.$-salen], and $\mathrm{N}, \mathrm{N}^{\prime}$-bis(3-nitrosalicylidene)-o-ethylenediamine [3,3'-( $\left.\mathrm{NO}_{2}\right)_{2}$-salen] (Table 1), were prepared using literature procedures [24]. Standard procedures for the synthesis of the trivalent metalsalen complexes $\left[\mathrm{Mn}^{\mathrm{II}}\right.$ (salen) $] \mathrm{Cl}, \quad\left[\mathrm{Mn}^{\mathrm{II}}\left\{5,5^{\prime}-\left(\mathrm{NO}_{2}\right)_{2^{-}}\right.\right.$ salen $\}] \mathrm{PF}_{6},\left[\mathrm{Mn}^{\mathrm{III}}\left\{5,5^{\prime}-(\mathrm{t} \mathrm{Bu})_{2}\right.\right.$-salen $\left.\}\right] \mathrm{OAc},\left[\mathrm{Mn}^{\mathrm{II}}\left\{3,3^{\prime}-\left(\mathrm{NO}_{2}\right)_{2^{-}}\right.\right.$

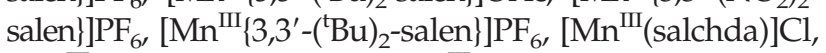
$\left[\mathrm{Mn}^{\mathrm{III}}(\right.$ salophen $\left.)\right] \mathrm{OAc}$, and [Mn $\left.{ }^{\mathrm{III}}(\mathrm{dsn})\right] \mathrm{OAc}$ have been described previously [25].

\section{Results and Discussion}

\section{Formation and Dissociation of $[\mathrm{M}-2 \mathrm{H}]^{-}$}

Figure 1 displays the negative-mode electrospray ionization (ESI) full-scan mass spectrum of a mixture of [ $\left[\mathrm{Mn}^{\mathrm{II}}\right.$ $\mathrm{I}($ salen) $] \mathrm{Cl}$ (Table 1, 1) and angiotensin III-Leu (RVYVHPL). The major peaks were those of the deprotonated $\mathrm{M}$ ions $[\mathrm{M}-\mathrm{H}]^{-}(881.4 \mathrm{Th})$ and the singly charged $\mathrm{Mn}(\mathrm{III})$ complex ions [Mn ${ }^{\mathrm{III}}$ (salen)(M - 2H)] ${ }^{-}$(1201.4 Th); the single charge of the latter ions was readily determined from the isotopic distribution of their peaks (see the inset to Figure 1). The formation of multiply charged transitionmetal complexes in the gas phase is generally a challenge, especially when they possess multiply charged anions, because of the propensity for charge separation (Coulombic explosion) to occur [26]. Electron-transfer from the deprotonated peptide to the metal complex may not always be more favorable than other competitive reactions. Thus, the auxiliary ligand should be chosen as one that binds strongly to the metal center, otherwise it will be displaced through a proton abstraction pathway [27-31]. The strategy we used in this study was similar to that used for the formation of $\mathrm{M}^{+}$and $[\mathrm{M}+\mathrm{H}]^{2+}$ ions from 
Table 1. Dissociation pathways and structures of $\left[\mathrm{Mn}^{\mathrm{III}}(\mathrm{L})(\mathrm{M}-2 \mathrm{H})\right]^{\bullet-}$ systems.

\section{Chart 1}

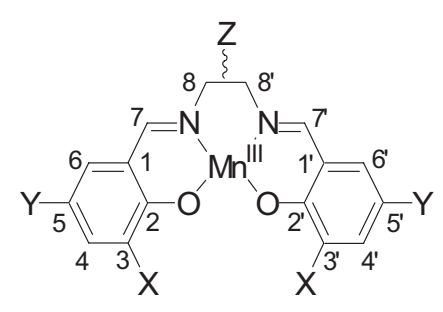

$\bullet-$

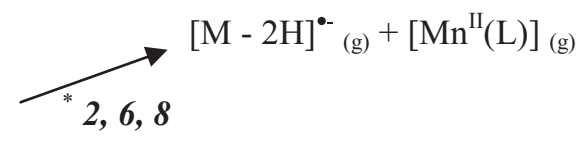

$(\mathrm{M}-2 \mathrm{H})$

(g)
$1,3,4,5,7$
$\longrightarrow[\mathrm{M}-\mathrm{H}]_{(\mathrm{g})}^{-}+\left[\mathrm{Mn}^{\mathrm{III}}(\mathrm{L}-\mathrm{H})\right]_{(\mathrm{g})}^{\bullet}(\mathrm{b})$

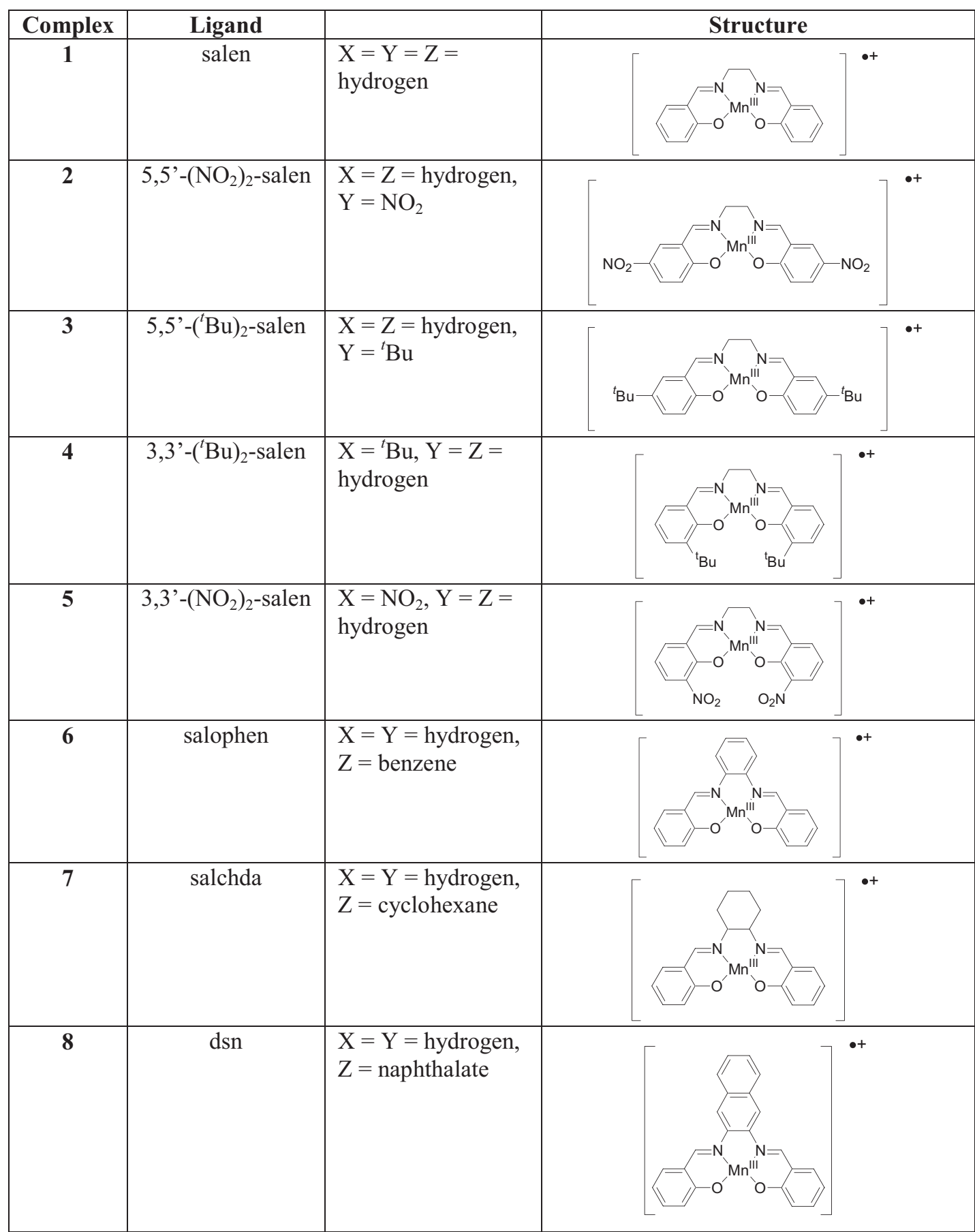

With predominant product ions being $[\mathrm{M}-2 \mathrm{H}]^{\circ-}$ or $[\mathrm{M}-\mathrm{H}]^{-}$. 


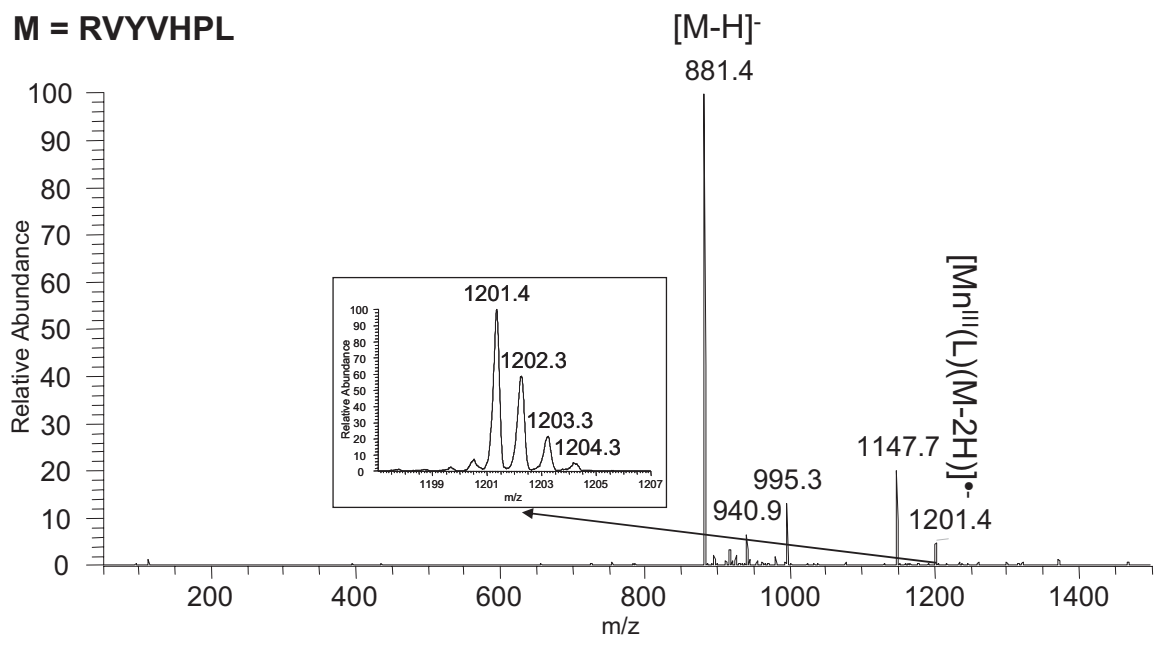

Figure 1. Full-scan spectrum of $\left[\mathrm{Mn}^{\mathrm{III}}(\text { salen })(\mathrm{M}-2 \mathrm{H})\right]^{-}{ }^{-}$, where $\mathrm{M}=\mathrm{RVYVHPL}$. A detailed view of the spectrum is presented in the inset.

copper(II) or transition-metal(III) complexes [27, 32]. Anionic salen ligands chelated to tricationic transition-metal complexes (namely, those of $\mathrm{Cr}, \mathrm{Mn}, \mathrm{Fe}$, or $\mathrm{Co}$ ) were good candidates for our initial investigations, partly because both the monoanionic parent of the [metal(III)(salen)(peptide $-2 \mathrm{H})]^{-}$complex and the product [peptide $\left.-2 \mathrm{H}\right]^{-}$ are observable through CID experiments performed in the negative-ion mode (cf. [Cu ${ }^{\mathrm{II}}($ salen) $(\mathrm{M}-2 \mathrm{H})$ ], which is present in neutral form) and partly because various transition-metal(III)-salen complexes have been demonstrated by $\mathrm{O}^{\prime}$ Hair et al. to generate abundant transient radical cationic hexapeptides of leucine encephalin derivatives [32]. Because Mn has the highest third-ionization potential among the elements $\mathrm{Cr}, \mathrm{Mn}, \mathrm{Fe}$, and $\mathrm{Co}(31.0$, 33.7, 30.5, and $33.5 \mathrm{eV}$, respectively) [33] and because the $\mathrm{Mn}(\mathrm{III})-$ salen complex is the most effective among these four metals in facilitating the generation of radical cationic peptides [32], we believed that the $\left[\mathrm{Mn}^{\mathrm{III}}(\text { salen })\right]^{+}$complex 1 (Table 1) also would be a good candidate for generating $[\mathrm{M}-2 \mathrm{H}]^{--}$ions. Figure 2 provides a lowenergy CID spectrum of $\left[\mathrm{Mn}^{\mathrm{III}}(\text { salen })(\mathrm{M}-2 \mathrm{H})\right]^{--}$ions. It is apparent that proton transfer from the $\mathrm{Mn}$ (III)-peptide

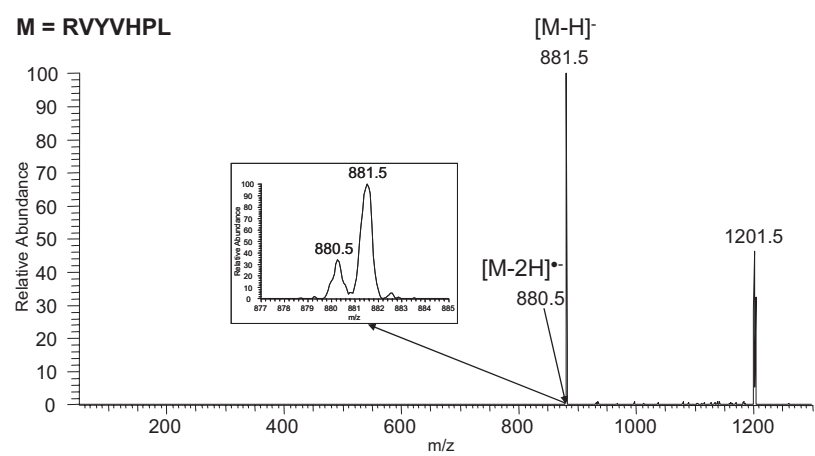

Figure 2. CID Spectrum with 1.5-2.5 Th isolation window of $\left[\mathrm{Mn}^{\mathrm{III}} \text { (salen) }(\mathrm{M}-2 \mathrm{H})\right]^{-}$, where $\mathrm{M}=\mathrm{RVYVHPL}$. The amplitude of the resonance excitation RF voltage was $1.20 \mathrm{eV}$. A detailed view of the spectrum of $[\mathrm{M}-2 \mathrm{H}]^{-}$is presented in the inset. complex to the peptide (Table 1, Reaction b) was predominant, generating the most abundant peak for $[\mathrm{M}-\mathrm{H}]^{-}$at 881.5 Th. It is important to note that we observe the first example of a novel anionic radical $[\mathrm{M}-2 \mathrm{H}]^{-}$at $880.5 \mathrm{Th}$ (inset of Figure 2), albeit in low abundance, formed through a one-electron transfer reaction (Table 1, Reaction a) by homolytic cleavage of the $\mathrm{Mn}(\mathrm{III})$ - peptide bond.

\section{Dissociation and Characterization of $[\mathrm{M}-2 \mathrm{H}]^{-}$}

To the best of our knowledge, no experimental studies have been reported so far describing the formation and characterization of anionic radical peptides $[\mathrm{M}-2 \mathrm{H}]^{-}$ through the use of low-energy CID. Dissociation of the [M $-2 \mathrm{H}]^{--}$radical anion of angiotensin III-Leu (RVYVHPL) leads to a number of abundant fragment ions (Figure 3a), including those arising from facile side-chain cleavages of the tyrosine, arginine, and leucine residues [p-quinomethide $\left\{\mathrm{CH}_{2}=\mathrm{C}_{6} \mathrm{H}_{4}=\mathrm{O}, 106 \mathrm{Da}\right\}$, N-allylguanidine $\left\{\mathrm{CH}_{2}\right.$ $\left.=\mathrm{CHCH}_{2} \mathrm{NHCNH}\left(\mathrm{NH}_{2}\right), 99 \mathrm{Da}\right\}$, and 2-methylpropene $\left\{\mathrm{CH}_{2}=\mathrm{C}\left(\mathrm{CH}_{3}\right)_{2}, 56 \mathrm{Da}\right\}$, respectively], $\mathrm{C}_{\beta}-\mathrm{C}_{\gamma}$ side-chain cleavages of the leucine and arginine residues [ethyl radical $\left\{\mathrm{CH}\left(\mathrm{CH}_{3}\right)_{2}, 43 \mathrm{Da}\right\}$ and $\mathrm{N}$-ethylguanidine radical $\left\{\mathrm{CH}_{2} \mathrm{CH}_{2} \mathrm{NHCNH}\left(\mathrm{NH}_{2}\right)\right.$; $\left.86 \mathrm{Da}\right\}$, respectively], $\mathrm{N}-\mathrm{C}_{\alpha}$ bond cleavages of the peptide backbone to produce $\left[z_{n}+\right.$ $\mathrm{H}]^{--}$and $\left[\mathrm{z}_{\mathrm{n}}-\mathrm{H}\right]^{--}$ions, and minor fragment ions arising from the cleavages of $\mathrm{C}_{\alpha}-\mathrm{C}$ bonds to generate $\left[\mathrm{x}_{\mathrm{n}}+\mathrm{H}\right]^{--}$ ions. Conversely, some common fragments of deprotonated peptides, e.g., $b_{n}^{-}, c_{n}^{-}$, and $y_{n}^{-}$ions, are notably absent [34, 35]. Dissociation of the odd-electron peptide radical anions is significantly different from those of the corresponding even-electron $[\mathrm{M}-\mathrm{H}]^{-}$species, as indicated in the inset of Figure 3a. Parenthetically, the electron detachment dissociation (EDD) of deprotonated radical anionic peptides has been demonstrated to promote unique peptide cleavages of $\mathrm{C}_{\alpha}-\mathrm{C}$ bonds to form predominantly $x$ and a product ions, which are quite distinct product ions than those formed from 
(a)

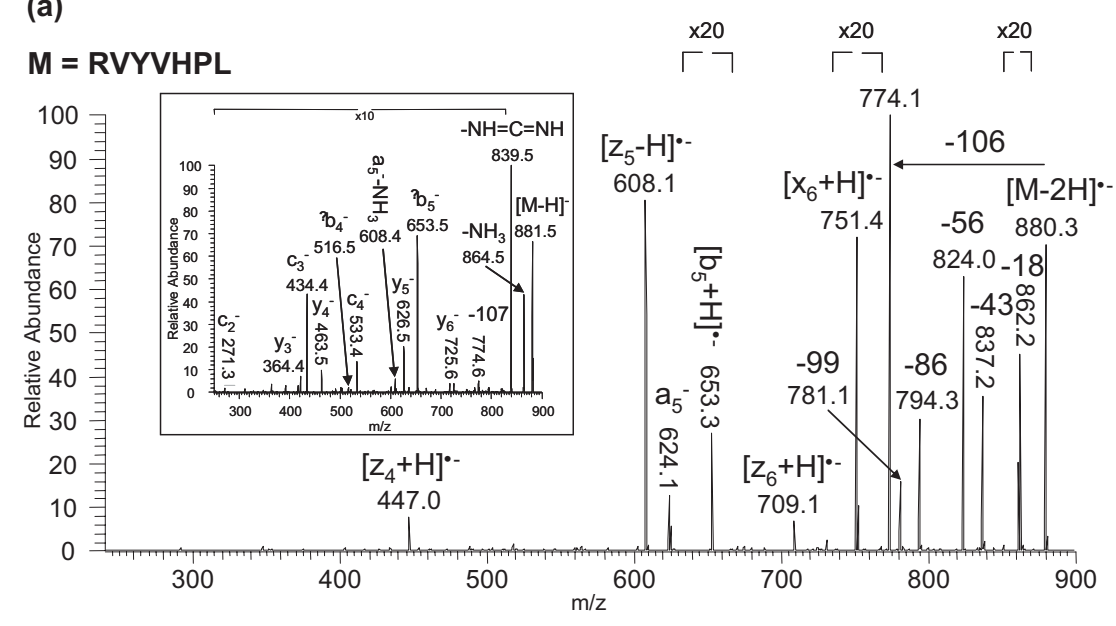

(b)

\section{M = RVYVHPF}

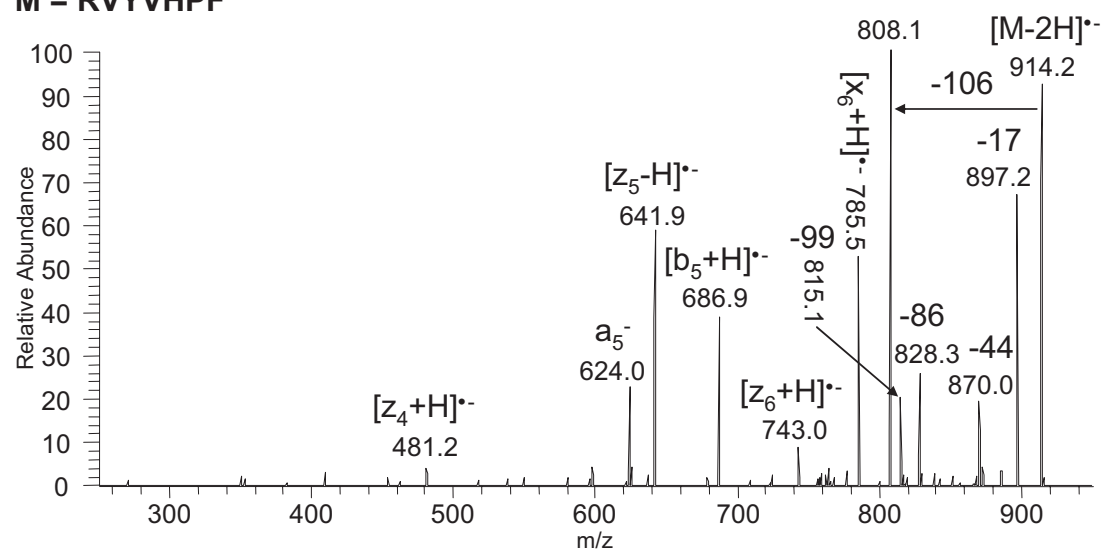

\section{(c)}

\section{$M=$ RAYVHPL}

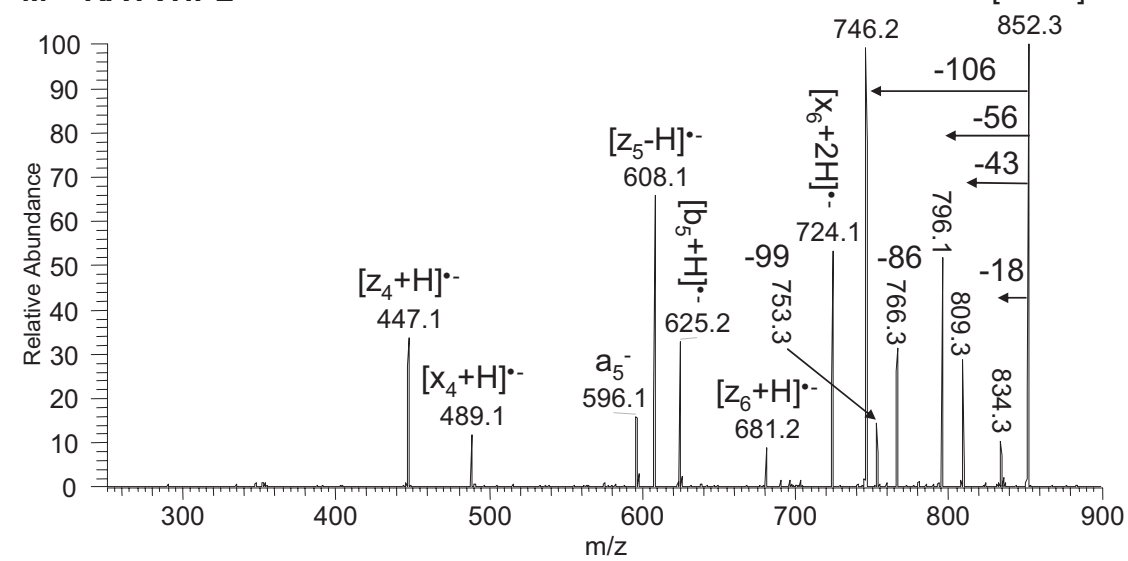

Figure 3. CID Spectra with unit resolution of $[\mathrm{M}-2 \mathrm{H}]^{--}$species where (a) $\mathrm{M}=\mathrm{RVYVHPL}$, (b) $\mathrm{M}$ $=$ RVYVHPF, and (c) M = RAYVHPL. The amplitudes of the resonance excitation RF voltage were $1.30,1.37$, and $1.26 \mathrm{eV}$, respectively. The $\mathrm{MS}^{2}$ spectrum of $[\mathrm{M}-\mathrm{H}]^{-}$ion is presented in the inset of (a).

$[\mathrm{M}-2 \mathrm{H}]^{--}$ions though the CID of $\left[\mathrm{Mn}^{\mathrm{III}}(\right.$ salen$)(\mathrm{M}-$ $2 \mathrm{H})]^{--}$complexes $[10,36]$. We verified the fragmentation patterns of the radical anionic peptides by recording the CID spectra of a series of angiotensin III derivatives that differ only by the nature of their $\mathrm{N}$ - or C-terminal amino acid residue. By substituting leucine with phenylalanine at the C-terminus of angiotensin III-Leu, we reconfirmed the assignments of the C-terminal fragment ions $\left(\left[\mathrm{x}_{\mathrm{n}}+\mathrm{H}\right]^{-},\left[\mathrm{z}_{\mathrm{n}}+\mathrm{H}\right]^{--}\right.$, and $\left.\left[\mathrm{z}_{\mathrm{n}}-\mathrm{H}\right]^{--}\right)$by observing a mass shift of $\mathrm{m} / \mathrm{z} 34$ 


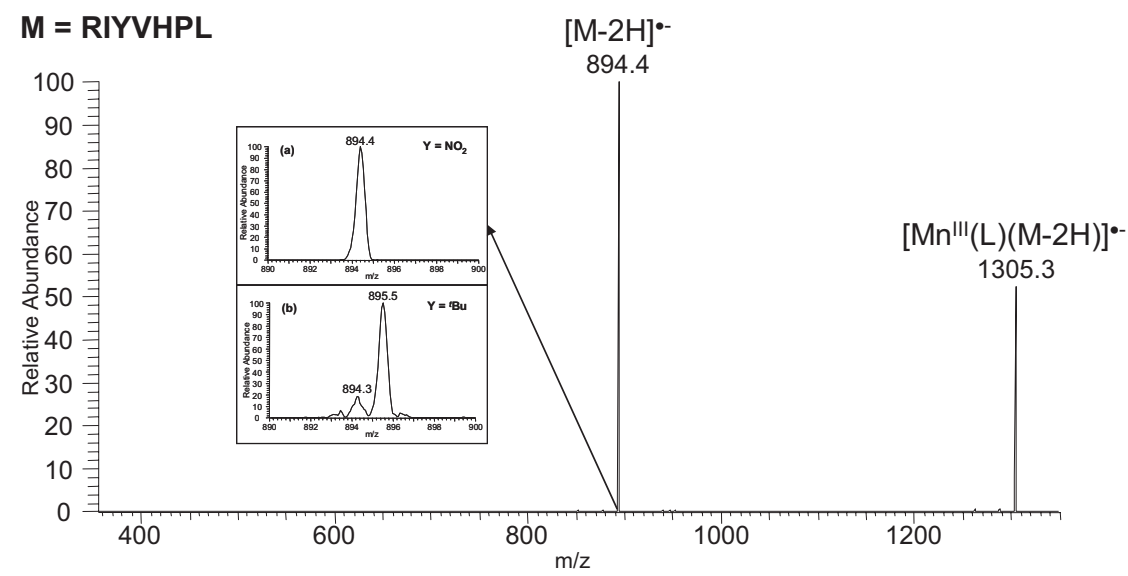

Figure 4. CID Spectrum with unit resolution of $\left[\mathrm{Mn}^{\mathrm{III}}\left\{5,5^{\prime}-\left(\mathrm{NO}_{2}\right)_{2}-\text { salen }\right\}(\mathrm{M}-2 \mathrm{H})\right]^{-}$, where $\mathrm{M}=$ RIYVHPL. The amplitude of the resonance excitation RF voltage was $2.51 \mathrm{eV}$. Detailed spectra of the $[\mathrm{M}-2 \mathrm{H}]^{--}$species obtained from the (a) $\left[\mathrm{Mn}^{\mathrm{III}}\left\{5,5^{\prime}-\left(\mathrm{NO}_{2}\right)_{2} \text {-salen }\right\}(\mathrm{M}-2 \mathrm{H})\right]^{-}$and (b) $\left[\mathrm{Mn}^{\mathrm{III}}\left\{5,5^{\prime}-\right.\right.$ $\left({ }^{\mathrm{t}} \mathrm{Bu}\right)_{2}$-salen $\left.\}(\mathrm{M}-2 \mathrm{H})\right]^{-}$systems are presented as insets.

arising from the mass difference between the leucine and phenylalanine residues. The fragmentation pattern in the product ion spectrum of the RVYVHPF radical anion displayed in Figure $3 b$ is virtually identical to that in Figure 3a. Similarly, we confirmed the N-terminal fragment ions (i.e., $a_{n}{ }^{-}$and $\left[b_{n}+\right.$ $\mathrm{H}^{--}$) from the product ion spectrum of the angiotensin III-Leu (RVYVHPL) derivative after deliberately changing the second amino acid residue from valine to alanine (Figure 3c). As expected, the prominent C-terminal z-type ions retained their mass-to-charge ratios for their unsubstituted moieties (e.g., for $\left[z_{4}+\right.$ $\mathrm{H}]^{--}$and $\left[\mathrm{z}_{5}-\mathrm{H}\right]^{--}$species), but display mass increases of $m / z 28$ (e.g., for $\left[\mathrm{z}_{6}+\mathrm{H}\right]^{--}$) for alanylcontaining fragment ions. The CID spectra in Figure $3 a-c$ reveal similar types of ions, a number of which, e.g., the $\left[\mathrm{x}_{\mathrm{n}}+\mathrm{H}\right]^{--},\left[\mathrm{z}_{\mathrm{n}}+\mathrm{H}\right]^{--}$, and $\left[\mathrm{z}_{\mathrm{n}}-\mathrm{H}\right]^{--}$, are not commonly observed after either the $\operatorname{EDD}[10,36]$ or electron transfer dissociation (ETD) of deprotonated radical anionic peptides [37].

Ligand Effects on the Formation of $[\mathrm{M}-2 \mathrm{H}]^{-}$: Electronic Effects of Substituents at the 5 and 5' Positions

We extended our systematic studies to examine how the metal complexes and, particularly, the auxiliary ligands affect the various competitive dissociation pathways in an effort to achieve the efficient formation of radical anionic peptides. To determine some of the fundamental parameters that govern the formation of radical anionic peptides, we examined the effects of various ligands (Table 1) that exhibit different steric and electronic properties. As an illustration, the CID spectrum (see inset a of Figure 4 ) of the $\left[\mathrm{Mn}^{\mathrm{III}}\left\{5,5^{\prime}-\left(\mathrm{NO}_{2}\right)_{2^{-}}\right.\right.$ salen $\}(\mathrm{M}-2 \mathrm{H})]^{--}$complex 2 (where $\mathrm{M}=$ RIYVHPL), whose ligand possesses electron-withdrawing $\mathrm{NO}_{2}$ groups, displays product ions that are distinct from those of the corresponding $\left[\mathrm{Mn}^{\mathrm{III}}(\text { salen })(\mathrm{M}-2 \mathrm{H})\right]^{-}$ complex; i.e., in this case the $[\mathrm{M}-2 \mathrm{H}]^{--}$ions dominate. In contrast, the $\left[\mathrm{Mn}^{\mathrm{III}}\left\{5,5^{\prime}-\left({ }^{\mathrm{t}} \mathrm{Bu}\right)_{2} \text {-salen }\right\}(\mathrm{M}-2 \mathrm{H})\right]^{-}$ complex 3 with its electron-donating ${ }^{\mathrm{t}} \mathrm{Bu}$ groups exhibited moderated homolytic cleavage of the metal-peptide bond, such that peptide fragmentation occurred more readily to result in $[\mathrm{M}-\mathrm{H}]^{-}$ species as the most prominent ions (see inset $b$ of Figure 4). These trends regarding the electronic and steric effects during the formation of $[\mathrm{M}-2 \mathrm{H}]^{-}$ species are in accordance with the results described by $\mathrm{O}^{\prime}$ Hair et al. for the enhanced generation of radical cationic hexapeptides [32].

Ligand Effects on the Formation of $\left[\mathrm{M}-2 \mathrm{H}^{-}\right.$: Steric Effects of Substituents at the 3 and 3' Positions

In previous studies, we have demonstrated that a wide variety of peptide radical cations $\left(\mathrm{M}^{+}\right)$can be produced after altering the structure of the auxiliary ligand on the copper atom $[38,39]$. In particular, the degree of steric hindrance or steric constraint about the auxiliary ligands is a major factor that determines whether the electron-transfer pathway predominates. In contrast, for the generation of peptide radical anions, our present CID spectra obtained when using the sterically encumbered ligand $3,3^{\prime}-\left({ }^{\mathrm{t}} \mathrm{Bu}\right)_{2}$-salen in complex 4 are essentially the same as those recorded when the ligand was salen or withdrawing substituents on 3,3'-( $\left(\mathrm{NO}_{2}\right)_{2}$-salen (complex 5); i.e., bulky (Figure 5b) or electron withdrawing (Figure 5a) substituent groups do not appear to exert any major influence. The enhanced degree of radical formation from $\mathrm{Cu}$ (II) complexes involving constrained macrocyclic ligands has been ascribed to the small geometrical change between the reduced and oxidized states rendering electron transfer [40-42]. The effect of the bulky groups at 3 and $3^{\prime}$ positions of the $\mathrm{Mn}(\mathrm{III})$-salen complexes is somewhat different from that of the copper(II) complexes because the former case 


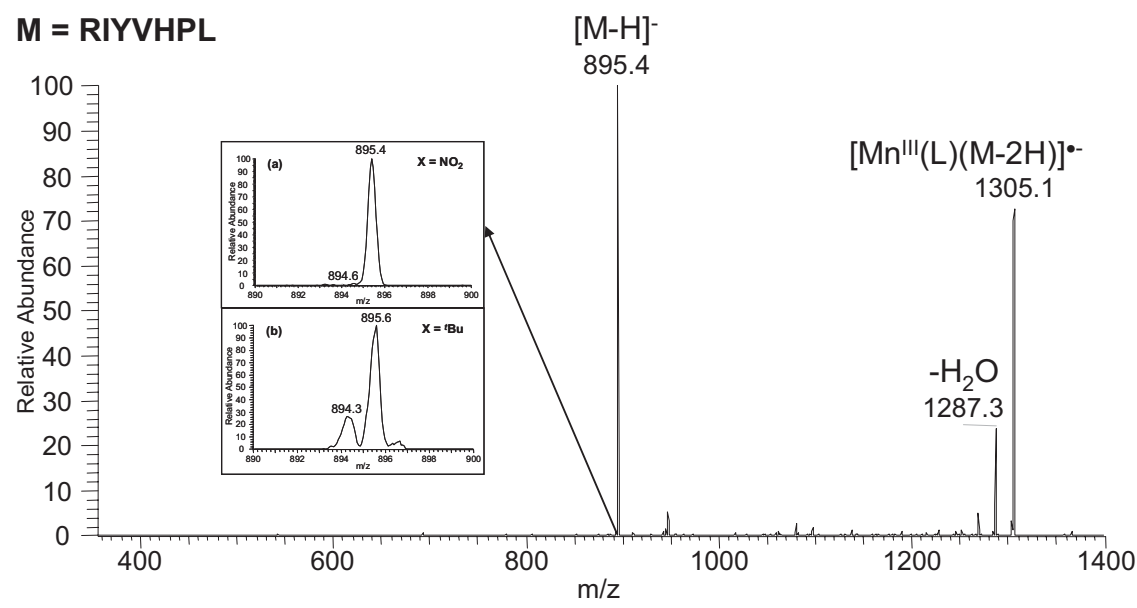

Figure 5. CID Spectrum with unit resolution of $\left[\mathrm{Mn}^{\mathrm{III}}\left\{3,3^{\prime}-\left(\mathrm{NO}_{2}\right)_{2}-\text { salen }\right\}(\mathrm{M}-2 \mathrm{H})\right]^{-}$, where $\mathrm{M}=$ RIYVHPL. The amplitude of the resonance excitation RF voltage was $2.00 \mathrm{eV}$. Detailed spectra of the $[\mathrm{M}-2 \mathrm{H}]^{--}$species obtained from the (a) $\left[\mathrm{Mn}^{\mathrm{III}}\left\{3,3^{\prime}-\left(\mathrm{NO}_{2}\right)_{2} \text {-salen }\right\}(\mathrm{M}-2 \mathrm{H})\right]^{-}$and (b) $\left[\mathrm{Mn}^{\mathrm{III}}\left\{3,3^{\prime}-\right.\right.$ $\left({ }^{\mathrm{t}} \mathrm{Bu}\right)_{2}$-salen $\left.\}(\mathrm{M}-2 \mathrm{H})\right]^{--}$systems are presented as insets.

involves octahedral six-coordinate geometry and the latter a distorted trigonal bipyramidal five-coordinate geometry. $\mathrm{Mn}(\mathrm{II})-$ salen complexes typically possess square-planar geometries, with two weakly bonded coordination sites. Thus, the ability of an auxiliary ligand in a Mn(III)-salen complex to adopt a "reduced state"-like square-planar structure may facilitate electron transfer. Crystal structures of Mn(III)-salen complexes have demonstrated that salen ligands twist slightly when binding to manganese ions with their tert-butyl groups arranged in equatorial conformation with respect to the ligand, rendering the two unoccupied axial sites available for the peptide to interact freely with the $\mathrm{Mn}(\mathrm{III})$ ion $[43,44]$. Thus, the bulky ${ }^{\mathrm{t}} \mathrm{Bu}$ groups located at the 3 and $3^{\prime}$ positions may not sufficiently hinder the coordination geometry of the $\left[\mathrm{Mn}^{\mathrm{III}}(\mathrm{L})(\mathrm{M}-2 \mathrm{H})\right]^{--}$complex when it adopts the reduced form $\left[\mathrm{Mn}^{\mathrm{II}}(\mathrm{L})\right]$ and, thereby, it does not lead to the efficient formation of $[\mathrm{M}-2 \mathrm{H}]^{--}$species.

Ligand Effects on the Formation of $\left[\mathrm{M}-2 \mathrm{H}^{-}{ }^{-}\right.$: Effect of Steric Constraint of Substituents at the 8 and 8 'Positions

An additional intriguing question is whether changes in the coordination geometry of the complex would enhance the formation of anionic radical peptides [M $2 \mathrm{H}^{-}$from $\mathrm{Mn}(\mathrm{III})-$ salen complexes. We examined the effects that sterically constrained auxiliary ligands have on the electron-transfer reaction by comparing the effects of an auxiliary ligand having a flexible cyclohexyl bridge at the 8 and $8^{\prime}$ positions with those of analogous ligands possessing more rigid phenyl and naphthyl moieties. The $\left[\mathrm{Mn}^{\mathrm{III}}\right.$ (salophen $\left.)(\mathrm{M}-2 \mathrm{H})\right]^{-}$complex $(\mathrm{M}$ $=$ RIYVHPL), which contains the $\mathrm{N}, \mathrm{N}^{\prime}$-o-phenylenebis (salicylideneiminato) ligand 6, successfully moderated the degree of proton transfer such that electron transfer became more prominent. The CID of the [Mn ${ }^{\mathrm{III}}$ (salo- phen $)(\mathrm{M}-2 \mathrm{H})]^{--}$complex $(\mathrm{M}=\mathrm{RIYVHPL})$ generated comparable amounts of the $[\mathrm{M}-2 \mathrm{H}]^{--}$and $[\mathrm{M}-\mathrm{H}]^{-}$ fragment ions (see inset a of Figure 6). In contrast, dissociation of the $\left[\mathrm{Mn}^{\mathrm{III}}(\text { salchda })(\mathrm{M}-2 \mathrm{H})\right]^{--}$complex $(\mathrm{M}=$ RIYVHPL), which contains the cyclohexylcontaining ligand 7 , produced only $[\mathrm{M}-\mathrm{H}]^{-}$ions (see inset $b$ of Figure 6) and no $[\mathrm{M}-2 \mathrm{H}]^{-}$species. More significantly, the sterically more constrained $\mathrm{N}, \mathrm{N}^{\prime}-\mathrm{O}-$ naphthylenebis(salicylideneiminato) (dsn) complex 8 led to predominant radical anion formation (see inset $\mathrm{c}$ of Figure 6), which, although not quite at the same abundance as that provided by the $5,5^{\prime}\left(\mathrm{NO}_{2}\right)_{2}$-salen ligand, was a significant improvement over the effect of the o-phenylenediamine-containing ligand. In addition to their electronic effects, a simple interpretation of the enhanced degree of $[\mathrm{M}-2 \mathrm{H}]^{--}$formation is that the rigid confirmations of the salophen and dsn ligands lead to their $\left[\mathrm{Mn}^{\mathrm{III}}(\mathrm{L})(\mathrm{M}-2 \mathrm{H})\right]^{--}$complexes adopting more sterically constrained square-planar geometries; as a result, the relatively preorganized structures of the reduced $\left[\mathrm{Mn}^{\mathrm{II}}(\mathrm{L})\right]$ ' species facilitates the electron transfer (Table 1, Reaction a) $[45,46]$. This observation is in accordance with the recent results obtained using sterically constrained auxiliary macrocyclic ligands within copper(II) complex ions, which also facilitate the formation of radical cationic tripeptides [31, 38, 39]. The enhanced degree of radical formation resulting from the use of sterically constrained ligands bears similarity to the classical example of the entatic state of ligated copper(II) ions in metalloproteins, in which constrained ligated copper(II) complexes facilitate electron transfer by maintaining similar geometries in both their reduced and oxidized states [40-42].

\section{Conclusion}

In this paper, we provide the first unequivocal demonstration of the generation of anionic radical peptides [M 


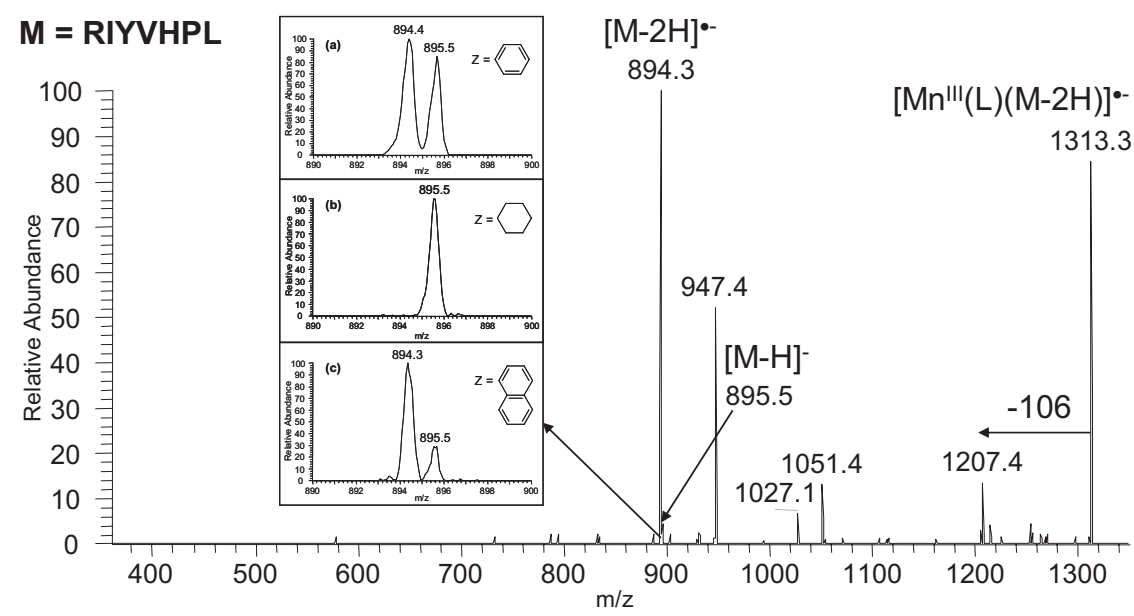

Figure 6. CID Spectrum with unit resolution of $\left[\mathrm{Mn}^{\mathrm{III}}(\mathrm{dsn})(\mathrm{M}-2 \mathrm{H})\right]^{-}$, where $\mathrm{M}=\mathrm{RIYVHPL}$. The amplitude of the resonance excitation RF voltage was $2.30 \mathrm{eV}$. Detailed spectra of the $[\mathrm{M}-2 \mathrm{H}]^{-}$ species obtained from the (a) $\left[\mathrm{Mn}^{\mathrm{III}}\right.$ (salophen $\left.)(\mathrm{M}-2 \mathrm{H})\right]^{--},(\mathbf{b})\left[\mathrm{Mn}^{\mathrm{III}}(\text { salchda })(\mathrm{M}-2 \mathrm{H})\right]^{---}$, and (c) $\left[\mathrm{Mn}^{\mathrm{III}}(\mathrm{dsn})(\mathrm{M}-2 \mathrm{H})\right]^{-}$systems are presented as insets.

$-2 \mathrm{H}^{--}$in the gas phase through the low-energy CID of $\left[\mathrm{Mn}^{\mathrm{III}}(\text { salen })(\mathrm{M}-2 \mathrm{H})\right]^{--}$complex ions. Fragmentation of $[\mathrm{M}-2 \mathrm{H}]^{--}$species led to through side-chain cleavage and the formation of sequence-specific fragment ions, z-type predominantly and x-type to some extent, that are distinct from those obtained from their evenelectron deprotonated counterparts $[\mathrm{M}-\mathrm{H}]^{-}$. We also examined the effects that the structures of the ligands have on the competitive dissociations occurring through electron and proton transfer reactions; we found that the formation of radical anionic angiotensin III was enhanced after substituting the auxiliary salen derivatives with electron withdrawing substituents at the 5 and $5^{\prime}$ positions or with sterically rigid substituents at the 8 and $8^{\prime}$ positions. Our experimental findings strongly suggest that CID methodology is applicable to the production of not only cationic radical peptides (i.e., $\mathrm{M}^{+}$and $[\mathrm{M}+\mathrm{H}]^{\cdot 2+}$ ) but also novel anionic radical peptides. In further investigations into these radical peptides $\left(\mathrm{M}^{+},[\mathrm{M}-2 \mathrm{H}]^{--}\right.$, and $\left.[\mathrm{M}+\mathrm{H}]^{-2+}\right)$, we will examine how the charge-carrying group of the radical peptide affects the mechanism of radical peptide fragmentation.

\section{Acknowledgments}

This study was supported by the University of Hong Kong (UGC) (project no. 200411159139 Seed Funding Program for Basic Research) and the Hong Kong Research Grants Council, Special Administrative Region, China (project no. HKU 7019/0 5P). CNWL thanks the Hong Kong RGC for supporting his studentships.

\section{References}

1. Biemann, K. Mass Spectrometry Organic Chemical Applications; McGrawHill: New York, 1962.

2. Biemann, K.; McCloskey, J. A. Mass Spectra of Organic Molecules. II. Amino Acids². J. Am. Chem. Soc. 1962, 84, 3192-3193.

3. Kemp, M.; Roiterg, A.; Mujica, V.; Wanta, T.; Ratner, M. A. Molecular Wires: Extended Coupling and Disorder Effects. J. Phys. Chem. 1996, 100, 8349-8355.
4. Schlag, E. W.; Lin, S. H.; Weinkauf, R.; Rentzepis, P. M. Dynamic Principles in Biological Processes. Proc. Natl. Acad. Sci. U.S.A. 1998, 95, 1358-1362.

5. Levis, R. J. Laser Desorption and Ejection of Biomolecules from the Condensed Phase into the Gas Phase. Annu. Rev. Phys. Chem. 1994, 45, 483-518.

6. Hodyss, R.; Cox, H. A.; Beauchamp, J. L. Bioconjugates for Tunable Peptide Fragmentation: Free Radical Initiated Peptide Sequencing (FRIPS). J. Am. Chem. Soc. 2005, 127, 12436-12437.

7. Zubarev, R. A.; Kelleher, N. L.; McLafferty, F. W. Electron Capture Dissociation of Multiply Charged Protein Cations. A Nonergodic Process. J. Am. Chem. Soc. 1998, 120, 3265-3266.

8. Kjeldsen, F.; Haselmann, K. F.; Sorensen, E. S.; Zubarev, R. A. Distinguishing of Ile/Leu Amino Acid Residues in the PP3 Protein by (Hot) Electron Capture Dissociation in Fourier Transform Ion Cyclotron Resonance Mass Spectrometry. Anal. Chem. 2003, 75, 1267-1274.

9. Mann, M.; Jensen, O. N. Proteomic Analysis of Post-Translational Modifications. Nat. Biotechnol. 2003, 21, 255-261.

10. Zubarev, R. A. Reactions of Polypeptide Ions with Electrons in the Gas Phase. Mass Spectrom. Rev. 2003, 22, 57-77.

11. Zubarev, R. A. Electron-Capture Dissociation Tandem Mass Spectrometry. Curr. Opin. Biotechnol. 2004, 15, 12-16.

12. Turecek, F.; Syrstad, E. A. Mechanism and Energetics of Intramolecular Hydrogen Transfer in Amide and Peptide Radicals and Cation-Radicals. J. Am. Chem. Soc. 2003, 125, 3353-3369.

13. Leymarie, N.; Costello, C. E.; O'Connor, P. B. Electron Capture Dissociation Initiates a Free Radical Reaction Cascade. J. Am. Chem. Soc. 2003, $125,8949-8958$

14. Turecek, F. N-C $\mathrm{C}_{\alpha}$ Bond Dissociation Energetics and Kinetics in Amide and Peptide Radicals. Is the Dissociation a Nonergodic Process? J. Am. Chem. Soc. 2003, 125, 5954-5963.

15. Breuker, K.; Oh, H. B.; Lin, C.; Carpenter, B. K.; McLafferty, F. W. Nonergodic and Conformational Control of the Electron Capture Dissociation of Protein Cations. Proc. Natl. Acad. Sci. U.S.A. 2004, 101, 14011-14016.

16. Kruger, N. A.; Zubarev, R. A.; Carpenter, B. K.; Kelleher, N. L.; Horn, D. M.; McLafferty, F. W. Electron Capture Versus Energetic Dissociation of Protein Ions. Int. J. Mass Spectrom. Ion Processes 1999, 182/183, 1-5.

17. Baba, T.; Hashimoto, Y.; Hasegawa, H.; Hirabayashi, A.; Waki, I. Electron Capture Dissociation in a Radio Frequency Ion Trap. Anal. Chem. 2004, 76, 4263-4266.

18. Silvra, O. A.; Kjeldsen, F.; Ivonin, I. A.; Zubarev, R. A. Electron Capture Dissociation of Polypeptides in a Three-Dimensional Quadrupole Ion Trap: Implementation and First Results. J. Am. Soc. Mass Spectrom. 2005, 16, 22-27.

19. Budnik, B. A.; Zubarev, R. A. $\mathrm{MH}^{2+}$ Ion Production from Protonated Polypeptides by Electron Impact: Observation and Determination of Ionization Energies and a Cross-Section. Chem. Phys. Lett. 2000, 316, 19-23.

20. Hvelplund, P.; Nielsen, S. B.; Sorensen, M.; Andersen, J. U. Electron Loss from Multiply Protonated Lysozyme Ions in High Energy Collisions with Molecular Oxygen. I. Am. Soc. Mass Spectrom. 2001, 12, $889-893$.

21. Chu, I. K.; Lam, C. N. W. Generation of Peptide Radical Dications Via Low-Energy Collision-Induced Dissociation of $\left[\mathrm{Cu}^{\mathrm{II}}(\text { terpy })(\mathrm{M}+\mathrm{H})\right]^{3+}$. J. Am. Soc. Mass Spectrom. 2005, 16, 1795-1804.

22. Kjeldsen, F.; Haselmann, K. F.; Budnik, B. A.; Jensen, F.; Zubarev, R. A. Dissociative Capture of Hot (3-13 eV) Electrons by Polypeptide Polyca- 
tions: An Efficient Process Accompanied by Secondary Fragmentation. Chem. Phys. Lett. 2002, 356, 201-206.

23. Chan, W. C.; White, P. D. Fmoc Solid Phase Peptide Synthesis: A Practical Approach; Oxford: New York, 2000.

24. Archer, R. D.; Chen, H. Synthesis, Characterization, and Luminescence of Europium(III) Schiff Base Complexes. Inorg. Chem. 1998, 37, 20892095.

25. Palucki, M.; Finney, N. S.; Pospisil, P. J.; Giiler, M. L.; Ishida, T.; Jacobsen, E. N. The Mechanistic Basis for Electronic Effects on Enantioselectivity in the (Salen)Mn(III)-Catalyzed Epoxidation Reaction. J. Am. Chem. Soc. 1998, 120, 948-854.

26. Schroder, D. Coulomb Explosions and Stability of Multiply Charged Ions in the Gas Phase. Angew. Chem. Int. Ed. 2004, 43, 1329-1331.

27. Chu, I. K.; Rodriquez, C. F.; Lau, T. C.; Hopkinson, A. C.; Siu, K. W. M. Molecular Radical Cations of Oligopeptides. J. Phys. Chem. B 2000, 104, 3393-3397.

28. Chu, I. K.; Rodriquez, C. F.; Lau, T. C.; Hopkinson, A. C.; Siu, K. W. M. Formation of Molecular Radical Cations of Enkephalin Derivatives via Collision-Induced Dissociation of Electrospray-Generated Copper (II) Complex Ions of Amines and Peptides. J. Am. Soc. Mass Spectrom. 2001, 12, 1114-1119.

29. Wee, S.; O'Hair, R. A. J.; McFadyen, W. D. Side-Chain Radical Losses from Radical Cations Allows Distinction of Leucine and Isoleucine Residues in the Isomeric Peptides Gly-XXX-Arg. Rapid Commun. Mass Spectrom. 2002, 16, 884-890.

30. Wee, S.; O'Hair, R. A. J.; McFadyen, W. D. Comparing the Gas-Phase Fragmentation Reactions of Protonated and Radical Cations of the Tripeptides GXR. Int. J. Mass Spectrom. 2004, 234, 101-122.

31. Barlow, C. K.; Wee, S.; McFadyen, W. D.; O'Hair, R. A. J. Designing Copper (II) Ternary Complexes to Generate Radical Cations of Peptides in the Gas Phase: Role of the Auxiliary Ligand. Dalton Trans. 2004, 3199-3204.

32. Barlow, C. K.; McFadyen, W. D.; O'Hair R. A. J. Formation of Cationic Peptide Radicals by Gas-Phase Redox Reactions with Trivalent Chromium, Manganese, Iron, and Cobalt Complexes. J. Am. Chem. Soc. 2005, 127, 6109-6115

33. Lide, D. R. CRC Handbook of Chemistry and Physics, 84th ed. CRC Press: Boca Raton, FL, 2004

34. Bowie, J. H.; Brinkworth, C. S.; Dua, S. Collision-Induced Fragmentations of the $[\mathrm{M}-\mathrm{H}]^{-}$Parent Anions of Underivatized Peptides: An Aid to Structure Determination and Some Unusual Negative Ion Cleavages. Mass Spectrom. Rev. 2002, 21, 87-107.

35. Harrison, A. G. Sequence-Specific Fragmentation of Deprotonated Peptides Containing H or Alkyl. J. Am. Soc. Mass Spectrom. 2001, 12, 1-13.

36. Kjeldsen, F.; Silivra, O. A.; Ivonin, I. A.; Haselmann, K. F.; Gorshkov, M.; Zubarev, R. A. $\mathrm{C}_{\alpha-} \mathrm{C}$ Backbone Fragmentation Dominates in Electron Detachment Dissociation of Gas-Phase Polypeptide Polyanions.Chem. Eur. I. 2005, 11, 1803-1812.

37. Coon, J. J.; Shabanowitz, J.; Hunt, D. F. Electron Transfer Dissociation of Peptide Anions. J. Am. Soc. Mass Spectrom. 2005, 16, 880-882.

38. Chu, I. K.; Lam, C. N. W.; Siu, S. O. Facile Generation of Tripeptide Radical Cations in Vacuo via Intramolecular Electron Transfer in $\mathrm{Cu}^{\mathrm{II}}$ Tripeptide Complexes Containing Sterically Encumbered Terpyridine Ligands. J. Am. Soc. Mass Spectrom. 2005, 16, 763-771.

39. Lam, C. N. W.; Siu, S. O.; Orlova, G.; Chu, I. K. Macrocyclic Effect of Auxiliary Ligand on the Gas-Phase Dissociation of Ternary Copper(II)GGX Complexes. Rapid Commun. Mass Spectrom. 2006, 20, 790-796.

40. Vallee, B. L.; Williams, R. J. P. Metalloenzymes: The Entatic Nature of their Active Sites. Proc. Natl. Acad. Sci. U.S.A. 1968, 59, 498-505.

41. Williams, R. J. P. Energized (Entatic) States of Groups and of Secondary Structures in Proteins and Metalloproteins. Eur. J. Biochem. 1995, 234, 363-381.

42. Gray, H. B.; Malmstrom, B. G.; Williams, R. J. P. Copper Coordination in Blue Proteins. J. Biol. Inorg. Chem. 2000, 5, 551-559.

43. Li, H.; Zhong, Z. J.; Duan, C.-Y.; You, X. -Z.; Mak, T. C. W.; Wu, B. Synthesis and Crystal Structure of a Manganese(III) Complex with the Tetradentate Schiff Base N,N'-Ethylenebis(Salicylideneiminato). J. Coord. Chem. 1997, 41, 183-189.

44. Jepsen, A. S.; Roberson, M.; Hazell, R. G.; Jorgensen, K. A. Crystal Structure of a Chiral Nitrido-Manganese Salen Complex. The Nitrogen Analog to the Intermediate in the Jacobsen Epoxidation Reaction. Chem. Commun. 1998, 15, 1599-1600.

45. Gallo, E.; Solari, E.; Re, N.; Floriani, C.; Chiesi-Villa, A.; Rizzoli, C. Dioxygen Activation by a Manganese Complex Containing a Schiff Base: Selective Oxidation of an Imino to an Amido Group within the Salophen Ligand and Formation of a Hydroxy-Bridged Mn ${ }^{\text {III-Polymer. }}$ Angew. Chem. Int. Ed. 1996, 35, 1981-1983.

46. Ciringh, Y.; Gordon-Wylie, S. W.; Norman, R. E.; Clark, G. R.; Weintraub, S. T.; Horwitz, C. P. Multinuclear Paramagnetic NMR Spectra and Solid State X-Ray Crystallographic Characterization of Manganese(III) Schiff-Base Complexes. Inorg. Chem. 1997, 36, 4968-4982. 